\title{
Study of the Chemical and Sensory Properties of a Calcium-milk Coagulum
}

\author{
Rahela Siamand ${ }^{1}$, Jasim M. S. Al-Saadi ${ }^{2 *}$ \\ ${ }^{1}$ Department of Food Science, Salahaddin University, Erbil, Iraq. \\ ${ }^{2}$ Department of Food Science, Sulaimani Polytechnic University, Halabja, Sulaimani, Iraq. \\ *Corresponding Author: jasim.salih@spu.edu.iq
}

Received| November 17, 2015

Accepted|January 6, 2016

\section{Abstract}

The chemical and sensory properties of a calcium-milk coagulum which were prepared from heated skim milk were investigated. The yield of calcium milk coagulum was $18.16 \%$, and this value was higher than the yield of soft cheese which was $10.6 \%$. At zero degree of cold storage, the moisture, total solids, acidity, lactose, proteins and ash $\%$ in calcium milk coagulum were $66.6,33.3,0.14,3.7,26.9$ and $1.7 \%$ respectively, While these values in soft cheese were $72,27.9,0.13,3.5,21.8$ and $1.4 \%$ respectively.

Sensory evolution scores for flavour, holes, bitterness, appearance $\&$ colour of calcium milk coagulum at zero degree and after 28 days of storage at $7 \pm 1^{\circ} \mathrm{C}$ were higher than soft cheese, while texture and body scores were less than soft cheese. After 14 days storage at $\left(7 \pm 1^{\circ} \mathrm{C}\right)$ the total bacterial count, Coliform count and fungi count of the soft cheese sample was significantly higher than that in calcium milk coagulum.

Key words: Milk coagulum, ionic calcium, cheese, sensory.

\section{Introduction}

Gelation of milk proteins is an important process in dairy manufacture. The resulting gels have long linear chains of molecules that are cross-linked at different points. The chains can be cross-linked with covalent bonds or non-covalent cross-links such as salt bridges, entanglements and microcrystalline regions (Damodaran, 1996).

$\backslash$ Gel formation occurs when protein-protein interactions lead to the formation of a threedimensional network capable of entraining water molecules. A balance between the attractive forces necessary to form a network and the repulsive forces necessary to prevent its collapse is required
(Zirbel and Kinsella, 1988; Mangino, 1984). The ability of various proteins to form different gel structures is very important to the food industry. The textural properties, sensory characteristics and yield of processed foods such as cheese, yoghurt, custards and sausages are directly related to the formation of protein gels during heating. (Clark, 1992).

Gelation is known to consist of two major steps: First, Partial denaturation of protein molecules; Second, gradual association or aggregation of the denatured proteins (Kinsella \& Whitehead, 1989). There are three major influences that determine the nature of the protein gel formed: first, environmental conditions, such as $\mathrm{pH}$, ionic 
strength, and mineral content. Second, protein composition, extent of denaturation, and concentration. Third, processing condition, such as heating and cooling rates (Aguilera, 1995; Hines \& Foegeding, 1993).

The gels can be induced through heating, cooling, and by changing specific molecular interactions. Heating denatures globular proteins and forms gels, the strength of which depends on the rate of heating, physicochemical properties, and the nature of the proteins in the system (Damodaran, 1996). Gels can also be formed by changing colloidal interactions using different $\mathrm{pH}$, salt concentrations and ionic strength, and enzyme action (Fox and McSweeney, 1998).

Several different types of protein gels are produced from milk and milk components. Acid gels are the most important due to their formation in yogurt and related products (Lucey and Singh, 1998). The mechanism of formation of acid gels is well understood and involves the reduction of the repulsive forces on the micelle as the $\mathrm{pH}$ is lowered towards the isoelectric point of the proteins. In yogurt manufacture, denatured whey proteins play an important role in the formation and stability of the gel. Whey proteins alone form heat-set gels when denatured at $>70^{\circ} \mathrm{C}$ (Mulverhil and Kinsella, 1987). This is the basis of the manufacture of some dairy products such as ricotta cheese.

The caseins in milk are considerably more heatstable than the whey proteins, but under intense heat treatment $\left(140^{\circ} \mathrm{C}\right.$ for $\left.>20 \mathrm{~min}\right)$, they too form gels; the gelation is $\mathrm{pH}$-dependent and this relationship is utilised in heat stability studies (Singh 2004). Protein gels are involving both whey proteins and caseins can form during roomtemperature storage of UHT-sterilised milk and concentrated milk products. This phenomenon, commonly known as "age gelation", limits the shelf-life of such products (Datta and Deeth, 2001). While the exact nature of the gel is unclear, it is known to involve the casein micelles embedded is a protein network composed of whey proteins as well as caseins released from the micelle (Nieuwenhuijse and van Boekel, 2003). Several factors affect the formation and strength of dairy gels. However, one of the most important is the concentration of electrolytes such as calcium salts. Removal of small amounts of ionic calcium by citrate, phosphate or ion exchange has been shown to improve the firmness of yogurt gels whereas removal of a large amount of calcium and addition of ionic calcium have adverse effects on the gels (Ozcan-Yilsav et al., 2007; Ramarubramanian et al., 2008). Several workers (Johns and Ennis, 1981; Schmidt and Morris 1984; Mulvihill and Kinsella, 1987) have reported that addition of electrolytes, such as calcium and sodium salts, affect the strength and texture of heat-set whey protein concentrate (WPC) gels. At low calcium concentrations, weak gels were formed, while at calcium concentrations up to 11 $\mathrm{mM}$, gels with increased strength were formed. Modler (1985) and Modler and Jones (1987) found that the addition of $5-20 \mathrm{mM} \mathrm{CaCl} 2$ or 0.1 to $0.3 \mathrm{M} \mathrm{NaCl}$ increased the gel strength of heated WPC. Calcium has also been shown to influence the gelation of casein in heat stability studies. In general, addition of ionic calcium reduces heat stability but also alters the heat stability-pH profile (Singh, 2004). 
Heating milk at $70^{\circ} \mathrm{C}$ with added calcium chloride at concentrations of 20 to $200 \mathrm{mM}$ causes coagulation of the proteins with release of whey (Ramasubramanian et al., 2012). However, when milk is heated with lower concentrations of added calcium chloride, a gel forms without release of whey (Ramasubramanian, 2013). Three effects, or a combination thereof, have been proposed to account for the role of calcium in greatly enhancing aggregation (Simons et al., 2002):

First, Interpreting ion bridges, involving carboxylic groups and the calcium ion (Mulvihill \& Kinsella, 1988). Second, Ion-induced conformational changes, leading to hydrophobic interactions (Jeyarajah \& Allen, 1994). Third, Electrostatic shielding of negative charges. De Wit et al. (1988) also demonstrated a relationship between ionic strength and gel formation. Removal of calcium and lactose before thermal processing followed by addition of calcium salts prior to gelation resulted in improved gel formation by whey proteins.

During the work of (Siamand et al., 2014) they were able to produce calcium-milk gel using heat treatment and calcium addition.

The main objective of this study was to produce coagulum from calcium-milk gel then characterize the chemical and sensory properties of calcium-milk coagulum in comparison with soft cheese. Such coagulum may provide the dairy industry with an attractive calcium-fortified product produced without the use of acid, or rennet.

\section{Materials and Methods}

Milk samples
Raw cow milk was collected from 13 cows by local Erbil farmers. Skim milk was produced by separation of raw milk with a separator.

Soft cheese and Calcium - milk coagulum manufacturing:

Soft cheese was made by pasteurization of skim milk at $63{ }^{\circ} \mathrm{C}$ for $30 \mathrm{~min}$. then cooled to $35{ }^{\circ} \mathrm{C}$, the rennet was added to milk followed by incubation at $35{ }^{\circ} \mathrm{C}$ for $40-45 \mathrm{~min}$ for coagulation, the curd was cut and left for $5 \mathrm{~min}$ and after that the curd was agitated gently and whey was drained .Salt (2\%) was added and the curd was molded and pressed. Cheese yield was calculated using the following equation:

Yield $(\%)=\frac{\text { wieght of cheese }}{\text { wieght of milk }} \times 100$

For manufacturing Calcium - milk coagulum, Skim milk was subject to pre-heat treatment at $85^{\circ} \mathrm{C}$ for $20 \mathrm{~min}$ and cooled to $\sim 22^{\circ} \mathrm{C}$. Calcium chloride was added to the milk to give added $\mathrm{Ca}^{2+}$ concentrations of $13.5 \mathrm{mM}$, and mixed thoroughly. The milk was then heated to $85^{\circ} \mathrm{C}$ and left undisturbed at this temperature for $20 \mathrm{~min}$ to produce a milk gels.

Gel was cut and left for $5 \mathrm{~min}$ and after that coagulum was agitated gently and whey was removed. Salt (2\%) was added and the curd was pressed. Coagulum yield was calculated using the above equation.

\section{Storage}

To study the changes in calcium-milk coagulum and cheese properties during storage ,the samples were stored at $7^{\circ} \mathrm{C}( \pm 1)$ and samples were taken for analysis after 1, 7,14, 21 and 28 days. 


\section{Determination chemical composition of} calcium - milk coagulum \& cheese:

Protein, moisture, TS, acidity and ash \% in calcium - milk coagulum \& cheese were determined according to AOAC 1980. NPN \% was determined according to (Ling, 1956). Lactose $\%$ in (calcium milk coagulum and soft cheese) samples was determined according to Acton (1977) method.

Polyacrylamide Gel Electrophoresis (PAGE)

Calcium milk coagulum and soft cheese samples were analyzed by the urea-PAGE method of Andrews (1983) using direct staining with Coomassie Brilliant Blue G-250. Electrophoresis was carried out on a vertical slab unit (BDH gel tank; BDH Merck) and Consort power supply. The electrophoresis gels were made up of stacking and separating gels containing $5 \%$ and $12.5 \%$ acrylamide, respectively.

Ten microliters of calcium milk coagulum and soft cheese solution $(2 \mathrm{mg} / \mathrm{mL})$ was dissolved in stacking gel buffer containing $8 \mathrm{M}$ urea and $0.1 \mathrm{M}$ $\beta$-mercaptoethanol and heated at $95^{\circ} \mathrm{C}$ for $5 \mathrm{~min}$ before analysis. The gels were run under constant voltage of $200 \mathrm{~V}$ for about 3.5 hours.

\section{Sensory evaluation}

The samples were served in small cups and evaluated by 8 trained panelists from among the staff of Food technology department, college of Agriculture, Salahaddin University. The samples were evaluated for flavor, appearance \& color, bitterness, texture holes and body for calcium milk coagulum \& cheese as stated by Conochie \& Sutherland (1965).The maximum score for each property was 10 .
Samples were served in a randomized order and evaluated in duplicate. Mineral water was used to rinse out the testers' mouths between consecutive samples. Tests were conducted in a standardized room.

\section{Microbiological tests}

\section{Enumeration of total Yeast and Molds}

PDA was used for enumerated yeast and mold count. Plates were incubated at $25^{\circ} \mathrm{C}$ for 5 days (ISO No. 6611, 2004).

\section{Enumeration of total Coliform}

MacConkey agar was used for enumerated coliform. Plates were incubated at $37^{\circ} \mathrm{C}$ for 24 hours (ISO No. 4832, 2005).

\section{Enumeration of total Count Plate}

Nutrient agar was used for enumerated of total bacteria. Plates were incubated at $30^{\circ} \mathrm{C}$ for 72 hours (ISO No. 4833, 2003).

\section{Statistical Analysis}

All data were analysed using Statistical program (SAS, 2005). The significant differences between means of traits included in this study were determined using the probability $(\mathrm{p} \leq 0.05)$.

\section{Results}

Yield and chemical properties of calcium milk coagulum and soft cheese

The yield of calcium milk coagulum and soft cheese is shown in (Table 1). The yield of calcium milk coagulum was $18.16 \%$, and this value was statically higher than the yield of soft cheese (10.6\%). 
Table 1: Yield of calcium milk coagulum and cheese.

\begin{tabular}{|c|c|}
\hline Curd type & Yield (\%) \\
\hline calcium milk coagulum & 18.16 \\
\hline soft cheese & 10.6 \\
\hline
\end{tabular}

The changes in the chemical properties of calcium milk coagulum in comparison to soft cheese during cold storage is summarized in (Table 2). The moisture content in calcium milk coagulum and soft cheese were 66.67 and $72.09 \%$ and these values changed to 61.67 and $64.53 \%$ respectively after 28 days of storage at $7 \pm 1^{\circ} \mathrm{C}$.

These decreasing in moisture was accompany with increasing of total solids content in calcium milk coagulum and soft cheese during storage and this related to losing water from curd during storage. Total solids in calcium milk coagulum and soft cheese were 33.33 and $27.91 \%$ and these values changed to 38.24 and $35.47 \%$ respectively after 28 days of storage at $7 \pm 1^{\circ} \mathrm{C}$. At zero degree the acidity of calcium milk coagulum and of soft cheese were 0.14 and $0.13 \%$ and these values increased gradually to 0.36 and $0.31 \%$ respectively after 28 days of storage at $7 \pm 1{ }^{\circ} \mathrm{C}$. This increase in acidity is due to the activity of microorganisms in conversion of residual lactose to lactic acid and formation of $\mathrm{H}^{+}$ions (Madkor et al., 1987), or due to the increase in total solids content in curd (Ozer et al., 1998).

Table 2: Sensory evaluation of calcium milk coagulum and soft cheese during storage for 28 days at $7 \pm 1{ }^{\circ} \mathrm{C}(\mathrm{A}$; calcium milk coagulum, B; cheese).

\begin{tabular}{|c|c|c|c|c|c|c|c|c|c|c|c|c|}
\hline \multirow{2}{*}{$\begin{array}{c}\text { Storage } \\
\text { time }\end{array}$} & \multicolumn{2}{|c|}{ Flavor } & \multicolumn{2}{|c|}{ Texture } & \multicolumn{2}{c|}{ Hole } & \multicolumn{2}{c|}{ Body } & \multicolumn{2}{c|}{ Bitterness } & \multicolumn{2}{c|}{$\begin{array}{c}\text { Appearance\& } \\
\text { color }\end{array}$} \\
\cline { 2 - 14 } & A & B & A & B & A & B & A & B & A & B & A & B \\
\hline 0 & $8.50^{\mathrm{ab}}$ & $6.33^{\mathrm{c}}$ & $8.33^{\mathrm{d}}$ & $9.66^{\mathrm{ab}}$ & $10.0^{\mathrm{a}}$ & $9.16^{\mathrm{a}}$ & $8.33^{\mathrm{c}}$ & $9.83^{\mathrm{ab}}$ & $9.66^{\mathrm{a}}$ & $9.16^{\mathrm{a}}$ & $10.0^{\mathrm{a}}$ & $9.66^{\mathrm{a}}$ \\
\hline 7 & $9.00^{\mathrm{a}}$ & $6.66^{\mathrm{c}}$ & $8.83^{\mathrm{cd}}$ & $9.66^{\mathrm{ab}}$ & $10.0^{\mathrm{a}}$ & $9.33^{\mathrm{a}}$ & $9.00^{\mathrm{ab}}$ & $10.0^{\mathrm{a}}$ & $9.50^{\mathrm{a}}$ & $9.50^{\mathrm{a}}$ & $10.0^{\mathrm{a}}$ & $9.50^{\mathrm{a}}$ \\
\hline 14 & $9.33^{\mathrm{a}}$ & $7.83^{\mathrm{b}}$ & $9.00^{\mathrm{bcd}}$ & $9.83^{\mathrm{a}}$ & $10.0^{\mathrm{a}}$ & $9.66^{\mathrm{a}}$ & $8.50^{\mathrm{c}}$ & $9.83^{\mathrm{ab}}$ & $9.33^{\mathrm{a}}$ & $9.00^{\mathrm{a}}$ & $10.0^{\mathrm{a}}$ & $9.50^{\mathrm{a}}$ \\
\hline 21 & $9.33^{\mathrm{a}}$ & $7.83^{\mathrm{b}}$ & $9.00^{\mathrm{bcd}}$ & $9.83^{\mathrm{a}}$ & $10.0^{\mathrm{a}}$ & $9.50^{\mathrm{a}}$ & $8.50^{\mathrm{c}}$ & $9.83^{\mathrm{ab}}$ & $9.66^{\mathrm{a}}$ & $8.66^{\mathrm{ab}}$ & $10.0^{\mathrm{a}}$ & $9.33^{\mathrm{a}}$ \\
\hline 28 & $9.33^{\mathrm{a}}$ & $8.33^{\mathrm{ab}}$ & $9.16^{\mathrm{abc}}$ & $9.83^{\mathrm{a}}$ & $9.83^{\mathrm{a}}$ & $9.50^{\mathrm{a}}$ & $8.66^{\mathrm{c}}$ & $9.83^{\mathrm{ab}}$ & $9.16^{\mathrm{a}}$ & $7.83^{\mathrm{b}}$ & $9.66^{\mathrm{a}}$ & $9.16^{\mathrm{a}}$ \\
\hline
\end{tabular}

Different letters (a, b, c, d, or combination of these) indicate the presence of significant differences between values within the column.

Lactose content at zero degree in calcium milk coagulum and soft cheese were 3.7 and $3.5 \%$ and these values changed to 2.6 and $2.3 \%$ respectively after 28 days of storage at $7 \pm 1^{\circ} \mathrm{C}$.

Protein content in calcium milk coagulum was significantly higher than soft cheese. Protein content in calcium milk coagulum at zero degree was $26.91 \%$, while protein content in soft cheese was $21.83 \%$. The PAGE of calcium milk coagulum and cheese (Figure 1) show the presence of whey proteins in calcium milk coagulum.

After 28 days of storage at $7 \pm 1^{\circ} \mathrm{C}$ the protein content increased in calcium milk coagulum and 


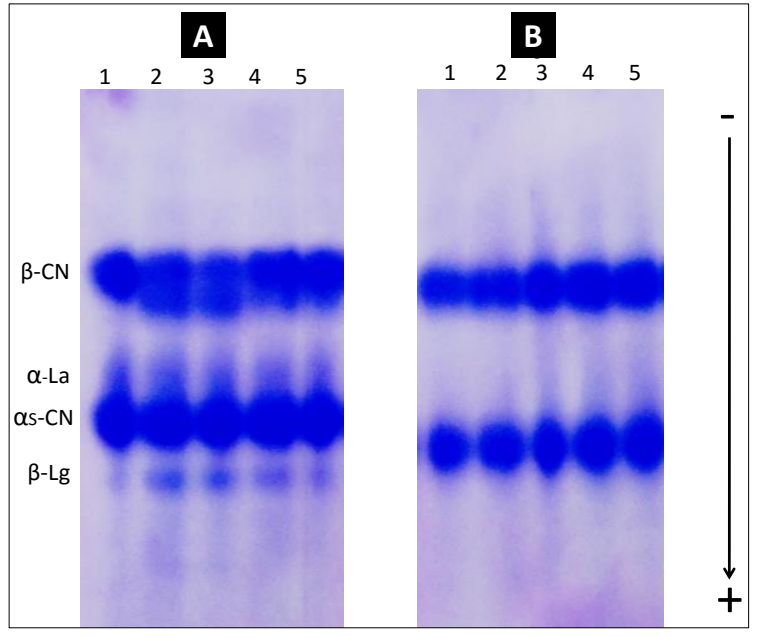

Figure 1: PAGE of calcium milk coagulum (a) and cheese (b) stored at $7 \pm 1^{\circ} \mathrm{C}$. 1 , zero degree; 2 , samples stored for 7 days; 3 , samples stored for 14 days; 4 , milk samples stored for 21 days; 5 samples stored for 28 days.

soft cheese to 31.79 and $28.95 \%$ respectively and this increase in protein content is related to the decrease in moisture in curd. NPN \% was determined as indicator for proteolysis in dairy products. NPN content in calcium milk coagulum and soft cheese at zero degree were 0.88 and $1.05 \%$ and these values increased to 1.09 and $1.21 \%$ respectively after 28 days of storage at $7 \pm 1{ }^{\circ} \mathrm{C}$.

Ash content in calcium milk coagulum and soft cheese at zero degree were 1.7 and $1.4 \%$ and these values increased to 2.9 and $2.7 \%$ respectively after 28 days of storage at $7 \pm 1^{\circ} \mathrm{C}$.

\section{Sensory evaluation of calcium milk coagulum and soft cheese}

Sensory evaluation scores of calcium milk coagulum and cheese during storage at $7 \pm 1{ }^{\circ} \mathrm{C}$ for 28 days is summarized in (Table 3 ).

Flavour scores of calcium milk coagulum and cheese at zero degree were 8.5 and 6.33 respectively. These values increased to 9.33 and 8.33 respectively after 28 days of storage at $7 \pm$ $1{ }^{\circ} \mathrm{C}$.

Table 3: Sensory evaluation of calcium milk coagulum and soft cheese during storage for 28 days at $7 \pm 1{ }^{\circ} \mathrm{C}(\mathrm{A}$; calcium milk coagulum, B; cheese).

\begin{tabular}{|c|c|c|c|c|c|c|c|c|c|c|c|c|}
\hline \multirow{2}{*}{$\begin{array}{c}\text { Storage } \\
\text { time }\end{array}$} & \multicolumn{2}{|c|}{ Flavor } & \multicolumn{2}{|c|}{ Texture } & \multicolumn{2}{c|}{ Hole } & \multicolumn{2}{c|}{ Body } & \multicolumn{2}{c|}{ Bitterness } & \multicolumn{2}{c|}{$\begin{array}{c}\text { Appearance\& } \\
\text { color }\end{array}$} \\
\cline { 2 - 12 } & A & B & A & B & A & B & A & B & A & B & A & B \\
\hline 0 & $8.50^{\mathrm{ab}}$ & $6.33^{\mathrm{c}}$ & $8.33^{\mathrm{d}}$ & $9.66^{\mathrm{ab}}$ & $10.0^{\mathrm{a}}$ & $9.16^{\mathrm{a}}$ & $8.33^{\mathrm{c}}$ & $9.83^{\mathrm{ab}}$ & $9.66^{\mathrm{a}}$ & $9.16^{\mathrm{a}}$ & $10.0^{\mathrm{a}}$ & $9.66^{\mathrm{a}}$ \\
\hline 7 & $9.00^{\mathrm{a}}$ & $6.66^{\mathrm{c}}$ & $8.83^{\mathrm{cd}}$ & $9.66^{\mathrm{ab}}$ & $10.0^{\mathrm{a}}$ & $9.33^{\mathrm{a}}$ & $9.00^{\mathrm{ab}}$ & $10.0^{\mathrm{a}}$ & $9.50^{\mathrm{a}}$ & $9.50^{\mathrm{a}}$ & $10.0^{\mathrm{a}}$ & $9.50^{\mathrm{a}}$ \\
\hline 14 & $9.33^{\mathrm{a}}$ & $7.83^{\mathrm{b}}$ & $9.00^{\mathrm{bcd}}$ & $9.83^{\mathrm{a}}$ & $10.0^{\mathrm{a}}$ & $9.66^{\mathrm{a}}$ & $8.50^{\mathrm{c}}$ & $9.83^{\mathrm{ab}}$ & $9.33^{\mathrm{a}}$ & $9.00^{\mathrm{a}}$ & $10.0^{\mathrm{a}}$ & $9.50^{\mathrm{a}}$ \\
\hline 21 & $9.33^{\mathrm{a}}$ & $7.83^{\mathrm{b}}$ & $9.00^{\mathrm{bcd}}$ & $9.83^{\mathrm{a}}$ & $10.0^{\mathrm{a}}$ & $9.50^{\mathrm{a}}$ & $8.50^{\mathrm{c}}$ & $9.83^{\mathrm{ab}}$ & $9.66^{\mathrm{a}}$ & $8.66^{\mathrm{ab}}$ & $10.0^{\mathrm{a}}$ & $9.33^{\mathrm{a}}$ \\
\hline 28 & $9.33^{\mathrm{a}}$ & $8.33^{\mathrm{ab}}$ & $9.16^{\mathrm{abc}}$ & $9.83^{\mathrm{a}}$ & $9.83^{\mathrm{a}}$ & $9.50^{\mathrm{a}}$ & $8.66^{\mathrm{c}}$ & $9.83^{\mathrm{ab}}$ & $9.16^{\mathrm{a}}$ & $7.83^{\mathrm{b}}$ & $9.66^{\mathrm{a}}$ & $9.16^{\mathrm{a}}$ \\
\hline
\end{tabular}

The scores given to calcium milk coagulum were significantly higher at significant level 0.05 . Texture and body score given for calcium milk coagulum were significantly lower than the scores given to soft cheese at zero degree and during storage for 28 days at $7 \pm 1^{\circ} \mathrm{C}$, and this is related to presence of whey proteins in calcium milk coagulum. The high water binding capacity of whey proteins, influences the texture of calcium milk coagulum, and make its protein matrix 
structure becomes coarser and more compact (Fox et al., 2000). The colour and appearance and holes scores of calcium milk coagulum and cheese were statically non-significant at level 0.05 .

Bitterness scores of calcium milk coagulum and soft cheese at zero degree were 9.66 and 9.16 and these values decreased to 9.16 and 7.83 respectively after 28 days of storage at $7 \pm 1^{\circ} \mathrm{C}$. In the first 2 weeks of storage there were no statically differences at level 0.05 between bitterness scores of calcium milk coagulum and cheese, but after 3 weeks of storage the differences became significant.

The scores given to calcium milk coagulum were higher than soft cheese scores and this may be related to the activity of rennet which attack casein, especially $\beta$ - casein and lead to the production of bitter peptides in cheese (Sullivan \& Jago, 1972).
Microbiological properties of calcium- milk coagulum and soft cheese

The microbiological properties of calcium milk coagulum and cheese is shown in (Table 4). In the first week of storage there was no microbial growth in calcium milk coagulum and cheese. After 14 days of storage the total bacterial count in soft cheese sample was significantly higher than total bacterial count in calcium milk coagulum. Coliform count and fungi count also were higher in soft cheese than calcium milk coagulum and this may relate to the higher heat treatment used in preparation of calcium milk coagulum in comparison with soft cheese. In general, after 28 days of storage at $7 \pm 1{ }^{\circ} \mathrm{C}$ the total bacterial count, coliform and fungi count in soft cheese were $10 \times 10^{4}, 4 \times 102$ and $3 \times 103(\mathrm{cfu} / \mathrm{gm})$, while these values in calcium milk coagulum were $5 \times 10^{4}, 3 \times 102$ and $2 \times 103$ (cfu/gm) respectively.

Table 4: Microbiological properties of calcium milk coagulum and soft cheese during storage for 28 days at $7 \pm 1$ ${ }^{\circ} \mathrm{C}$ (A; calcium milk coagulum, B; soft cheese).

\begin{tabular}{|c|c|c|c|c|c|c|}
\hline \multirow{2}{*}{$\begin{array}{c}\text { Storage } \\
(\text { days})\end{array}$} & \multicolumn{2}{|c|}{ T.C.P(cfu/gm) } & \multicolumn{2}{c|}{ Coliform (cfu/gm) } & \multicolumn{2}{c|}{ fungi(cfu/gm) } \\
\cline { 2 - 7 } & $\mathrm{A}$ & $\mathrm{B}$ & $\mathrm{A}$ & $\mathrm{B}$ & $\mathrm{A}$ & $\mathrm{B}$ \\
\hline 0 & - & - & - & - & - & - \\
\hline 7 & - & - & - & - & - & - \\
\hline 14 & $3 \times 10^{2 \mathrm{c}}$ & $3 \times 10^{4} \mathrm{bc}$ & $7 \times 10^{1 \mathrm{~b}}$ & $9 \times 10^{1 \mathrm{~b}}$ & $5 \times 10^{1 \mathrm{~d}}$ & $1 \times 10^{2 \mathrm{~d}}$ \\
\hline 21 & $4 \times 10^{2 \mathrm{bc}}$ & $4 \times 10^{4} \mathrm{~b}$ & $1 \times 10^{2 \mathrm{~b}}$ & $4 \times 10^{2} \mathrm{a}$ & $1 \times 10^{3 \mathrm{dc}}$ & $2 \times 10^{3 \mathrm{bc}}$ \\
\hline 28 & $5 \times 10^{4} \mathrm{a}$ & $10 \times 10^{4 \mathrm{a}}$ & $3 \times 10^{2 \mathrm{a}}$ & $1 \times 10^{3} \mathrm{~b}$ & $2 \times 10^{3} \mathrm{ab}$ & $3 \times 10^{3 \mathrm{a}}$ \\
\hline
\end{tabular}

\section{Discussion}

Yield and chemical properties of calcium milk coagulum and soft cheese

Higher yield of calcium milk coagulum in comparison with soft cheese may be related to the presence of whey proteins in calcium milk coagulum which increase the quantity of proteins in the curd (Al-Saadi and Deeth, 2011).

The increase in acidity was significantly higher in calcium milk coagulum than soft cheese and this can be explained by the effect of added calcium in 
increasing acidity of calcium milk coagulum (Ramasubramanian et al., 2012). The decreasing in lactose was due the activity of microorganisms which convert it to lactic acid .The higher microbial count in cheese (Table 4) explains the reason which made its lactose content lower than lactose content in calcium milk coagulum after 28 days of storage at $7 \pm 1^{\circ} \mathrm{C}$. While the increase in protein ratio in calcium milk coagulum was occur due to heat treatment which cross-linked whey proteins with caseins in the curd (Al-Saadi et al., 2013).

The higher increment in NPN in soft cheese at zero degree is due to the action of rennet on casein which cause the release of peptide from proteins (Hill et al., 1974), while the action of rennet and the higher bacterial count cause the higher increment of NPN soft cheese in comparison with calcium milk coagulum after 28 days of storage. The higher ash content in calcium milk coagulum in comparison with cheese is related to using of calcium in preparation this product, beside that the heat treatment used in preparation of this product convert calcium from free ionic form to colloidal form and this cause decreasing calcium concentration in whey and increase its bonding to casein micelles (Ramasubramanian et al., 2012).

\section{Conclusions}

Calcium milk coagulum was produced from skim milk using heat treatment and calcium chloride addition $(13.5 \mathrm{mM})$. The yield and protein content in calcium milk coagulum was significantly higher than soft cheese. Sensory properties and Microbiological quality of calcium milk coagulum was higher than soft cheese.

\section{Acknowledgment}

The authors wish to thank the staff of Food Science Department, Sulaimani Polytechnic University, Halabja, for their support.

\section{References}

Acton, G.H. (1977). The determination of Lactose in cheese. Australian Journal of Dairy Technology, 32, 11 .

Al-Saadi, J. M. \& Deeth, H. C. (2011). Preparation and functional properties of protein co-precipitate from sheep milk, International Journal of Dairy Technology, 64, 461-466.

Al-Saadi, J.M.S. Easa, A. M. \& Deeth, H. C. (2013). Effect of lactose on cross-.linking of milk proteins during heat treatments, International Journal of Dairy Technology, 63, 1-6.

Aguilera, J. M. (1995). Gelation of whey proteins. Food technology, 49, 83-89.

Andrews, A. T. (1983). Proteinases in normal bovine milk and their actions on caseins. Journal of Dairy Research, 50, 45-55.

Association of Official Analytical Chemists (AOAC) (1980). Official Methods of. Analysis, Washington DC: Association of Official Analytical .Chemists, 13 edition.

Clark, A. H. (1992). Gels and gelling. In Physical Chemistry of Foods.eds H. G. Schwartzberg \& R. W. Hartel. Marcel Dekker, New York, pp. 263-305.

Conochie, J. \& Sutherland, B.J. (1965). The nature and cause of seaminess in.Cheddar cheese.Journal of Dairy Research, 32, 35-44.

Datta, .N and Deeth, H. C. (2001). Age gelation of UHT milk - a review. Transactions of the Institute of Chemical Engineers C. Food and Bioproducts, Processing 79,197-210.

Damodaran, S. (1996) Amino acids, peptides, and proteins. In: Fennema OR, editor. Food chemistry. 3rd ed. New York, USA: Marcel Dekker, pp. $217-$ 329 .

De wit, J. N.; Hontelez-Backx, E. and Adamse, M. (1988). Evaluation of functional properties of whey protein concentrates and whey protein isolates.3. Functional properties in aqueous solution. Neth. Milk Dairy Journal, 42, 155-172.

Fox, P. F. and McSweeney, P.L.H. (1998). Dairy Chemistry and Biochemistry. Blackie Academic and Professional Publishers, London, New York. pp. 347-378

Fox, P. F. McSweeney, P. L. H. Cogan, T. M. \&Guinee, T. P. (2000). Fundamentals of cheese science. Gaithersburg: Aspen Publishers. p. 426. 
Hill, R. D. E. Lahav. \& Givol,D.(1974). A rennin sensitive bond in as1 B-casein.. Journal Dairy Research, 41,147-153.

Hines, M. E. and Foegeding, E. A. (1993). Interactions of $\alpha$-Lacalbumin and bovine serum albumin with $\beta$ Lactoglobulin in thermally induced gelation, Journal of Agricultural and Food Chemistry, 41,341-346

ISO 4833 (2003). Microbiology of food and animal feeding stuffs-Horizontal .method for the enumeration of the microorganisms -Colony count technique.at $30^{\circ} \mathrm{C}$.

ISO 6611 (2004). Milk and milk product -Enumeration of colony-forming units of .yeasts and/or mouldsColony count technique at $25^{\circ} \mathrm{C}$.

ISO 4832 (2005). Microbiology of food and animal feeding stuffs-Horizontal.method for the detection and enumeration of coliforms -Colony -count technique.

Jeyarajah, S. and Allen, J. C. (1994). Calcium-binding and salt-induced structural changes of native and preheated $\beta$-lactoglobulin, Journal of Agricultural and Food Chemistry, 42, 80-85.

Johns, J. E. M. and Ennis, B. M. (1981) .The effect of replacing calcium with sodium ions in acid whey on the functional property of whey protein concentrates. New Zealand Journal of Dairy Technology, 15 79-86.

Kinsella, J. E. and Whitehead, D. M. (1989). Proteins in whey: chemical, physical and functional properties. Advances in Food and Nutrition Research, 33, 433.438.

Ling, E.R. (1956). A text book of dairy chemistry .Vol. II practical, Chapman and Hall .LTD, (London).

Lucey, J. A. and Singh, H. (1998). Formation and physical properties of acid milk gels: a review. Food Research International, 30, 529-542.

Madkor, S. Fox, R. E. Shalabi, S. I. \&Metwalli,N. H.(1987). Studies on the ripening of Stilton cheese: proteolysis. Food Chemistry, 25, 13-29.

Mangino, M. E. (1984). Physicochemical aspects of whey protein functionality. Journal of Dairy Science, 67, 2711-2722.

Modler, H. W. J. (1985). Functional properties of nonfat dairy ingredients - A review modification of lactose and products containing whey proteins. Journal of Dairy Science, 68, 2206-2214.

Modler, H. W. and Jones, J. D. (1987). Selected processes to improve the functionality of dairy ingredients. Food Technology, 41, (10), 114-117.

Mulvihill, D. M. and Kinsella, J. E. (1987). Gelation characteristics of whey proteins and $\beta$ lactoglobulin. Food Technology, 41,(9) ,102-111.

Mulvihill, D. M. and Kinsella, J. E. (1988). Gelation of $\beta$-lactoglobulin - effects of sodium-chloride and calcium-chloride on the rheological and structuralproperties of gels, Journal of Food Science, 53, 231-236.
Nieuwenhuijse, J. A. and van Boekel, M. A. J. S. (2003). Protein stability in sterilised milk and milk products. In Advanced Dairy Chemistry, Volume 1 Proteins, P.F. Fox and P.J.H. McSweeney, eds, Elsevier Applied Science Publishers, London. pp. 947-974.

Ozcan-Yilsay, T.; Lee, W. J.; Horne, D. and Lucey, J. A. (2007). Effect of trisodium citrate on rheological and physical properties and microstructure of yogurt. Journal of Dairy Science, 90, 1644-1652.

Ozer, B. H. Bell, A. E. Grandison, A. S. \& Robinson, R. K. (1998). Rheological properties of concentrated yoghurt Labneh, Journal of Texture Studies, 29, 67-79.

Ramasubramanian, L. (2013). The interaction of ionic calcium and milk proteins during heat treatment. $\mathrm{PhD}$ thesis, The University of Queensland, Brisbane, Australia.

Ramasubramanian, L.; D'Arcy, B. R. and Deeth, H. C. (2012). Heat-induced coagulation of whole milk by high levels of calcium chloride. International Journal of Dairy Technology, 65, 183-190.

Ramasubramanian, L.; Restuccia, C. and Deeth, H. C. (2008). Effect of calcium on the physical properties of stirred probiotic yogurt. Journal of Dairy Science, 91, 4164-4175.

SAS. (2005). Statistical analysis system, User's guide for personal computer.Version 9.1 SAS Institute Inc. Cary،NC،USA.

Schmidt, R. H. and Morris, H. A. (1984). Gelation properties of milk proteins, soy proteins, and blended protein systems. Food Technology, 38, 8596.

Siamand, R.; Deeth, H. C. and Al-Saadi, J. M. (2014). Textural and sensory properties of a calciuminduced milk gel. Journal of Food Engineering, 139, 10-12.

Simons, J.; Kosters, H. A.; Visschers, R. W. and De Jongh, H. H. (2002). Role of calcium as trigger in thermal beta-lactoglobulin aggregation. Archives of Biochemistry and Biophysics, 406, 143-152.

Singh, H. (2004). Heat stability of milk. International Journal of Dairy Technology, 57, 111-119.

Sullivan, J. J. Jago, G. R. (1972). The structure of bitter peptides and their formation from caseins, Australian Journal Dairy Technology, 27,98-104.

Zirbel, F. and Kinsella, J. E. (1988). Factors affecting the rheological properties of gels made from whey protein isolate. Milchwissenschaft , $43,691-694$ 